Elsevier required licence: $(c)<2015>$. This manuscript version is made available under the CC-BY-NC-ND 4.0 license http://creativecommons.org/licenses/by-nc-nd/4.0/ 


\title{
Brave New World?
}

The global financial crisis' impact on Scandinavian Banking's sales rhetoric and practices

\begin{abstract}
The paper explores how the global financial crisis wrought changes in the financial industry, even far from the crisis' epicentre, in sales orientation, rhetoric and practices. We draw on accounts from managers and employees gleaned from a strategic sample of Scandinavian financial institutions. Framing our analysis in terms of Meyer's (1982) concept of environmental jolts, we identified a genealogical shift in accounts in relation to sales as the context changed: there was a transition from an early stress on blame games, through the nurturing of a more conceptual plurivocality, culminating in embellishment. Initially bankers blamed external actors and factors. Their rhetoric changed when they had to confront customer's complaints about overselling and mis-selling as well as critiques from regulatory authorities. A new discourse emerged focused on "right selling" and changes in sales practices but one still constituted in terms of the pressure to sell.
\end{abstract}

Key words: Sales rhetoric and practices, global financial crisis, jolt, reputation, re-orientation 


\section{Introduction}

There are many diverse scientific accounts on the global financial crises (GFC) (e.g. Knights, 2013, McDonald \& Robinson, 2009, Roubini \& Mihm, 2010, Stiglitz, 2010, Whittle \& Mueller, 2011). None have focused on it as a longitudinal process with everyday effects played out discursively. We investigate the crisis through accounts of changing financial cultures and conditions in Norway (authors, Engelstad 2013, The Financial Supervisory Authority, 2008$2013 ; 2014)$.

Traditionally, banks proud to be considered trustworthy lent money to customers after careful consideration of risks and the possibility of losses on a case-by-case basis based on local knowledge (Courpasson, 2006). Global deregulation, digital technology and increasing financialization changed the old world of finance (Reinhardt \& Rogoff, 2009; Zúniga-Vicente et al. 2005). Local knowledge was increasingly displaced by technical competence with computer programmes, aggressive selling tactics and a more meritocratic ethos (McDowell, 1997, McDonald \& Robinson, 2009). The 'financialization' of the global economy (Epstein, 2005; Røyrvik, 2011; Clegg et al., 2011) saw the key markets of London and New York, the City and Wall Street (Ho, 2009) become centres of the newly liberalized system of global flows of capital (Harvey, 2005; Foster \& Magdoff, 2009; Arrighi, 1994; Duménil \& Levy, 2004; Alexander, Dhumale \& Eatwell, 2005; Schinasi, 2005; Krugman, 2007). Credit derivatives were introduced, allowing risks to be turned into financial products that could be sold as shares or bonds (Tett, 2009; Ouroussoff, 2010). The structured finance investment vehicles provided financial institutions with opportunities to write swaps or options that provided them with regular payments in exchange for taking another's risk of default. With these changing conditions, front-line staff shifted from being 'tellers to sellers' (Regini, Kitay \& Baethge, 2000; Forseth, 2001; see also Korczynski \& Ott, 2005). Bank rates did not yield much return 
and complex new products with higher proposed yield were developed. Initially marketed to corporate clients as 'low risk', later they were sold to ordinary retail customers (authors).

The Global Financial Crisis (GFC) of 2008 jolted the finance industry (see for instance Stiglitz, 2009; Perrow, 2010). The term 'jolts', comes from Meyer (1982: 515), who -coined the term environmental jolts to capture the nature of unexpected, unplanned and uncertainty-inducing events. He defined these jolts as "transient perturbations whose occurrences are difficult to foresee and whose impact on organizations are disruptive and potentially inimical" (p. 515). The term was used "to distinguish external events from disparate interpretations within organizations such as opportunities, threats, crises, or catastrophes". Meyer underscored jolts as constituted by events whose reception is always ambiguous. In a case study of strategic managers in hospitals, Meyer concluded that jolts acquire their meanings from embedded ideologies that determined whether jolts were perceived as dilemmas, opportunities, or aberrations.

In our case, in the tradition of attending to the everyday cultures of finance (see, for instance, Ho, 2009; Whittle \& Mueller, 2011), we analyse longitudinal and ethnographic data to ask: 1) How did financial enterprises frame sales rhetoric and practices before the GFC? 2) How did financial enterprises respond to the critiques that arose after the GFC? 3) What attempts did financial enterprises make to rebuild image and trust in the wake of these post GFC critiques? After describing our data sources and methods, we will present the empirical section covering the trajectory of sales rhetoric and practices before, during and after the GFC.

\section{Material and methods}

\section{Case study}


When the global financial crisis occurred, we were conducting a study on sales cultures in finance. The turmoil made some processes related to sales more visible_-, but several negotiations about research collaboration came to an abrupt halt. Seemingly in limbo, in 2008, one author was invited to give a talk at a seminar on Human Resources organized by the Norwegian Employers' Association for Financial Services. Network contacts from the seminar and our previous research in finance helped us construct a sample of six Nordic players. We were also able to draw on empirical data from previous projects undertaken before the crisis, allowing us to chart early phases in the development of a sales orientation in banking and insurance. $^{1}$

\section{Context}

For this paper we mostly draw on data from four banks. Two of them come from a large Nordic financial service group with an emphasis on retail banking, offering a full range of financial services in several European countries. Its market position made it vulnerable to the crisis and it suffered greater economic losses than comparable regional institutions, making it an exemplary case (Flyvbjerg, Landman \& Schram, 2012). In addition, data from two saving banks in a Norwegian alliance less exposed to the economic effects of the global crisis, is included. To strengthen validity, we selected supplementary complementary cases: another major Nordic financial services group, one Norwegian financial services group, and one Norwegian and one Nordic insurance company. Due to reasons of anonymity, the names and further details of the cases are not provided - a prerequisite for gathering data.

\section{Sample and data gathering}

\footnotetext{
${ }^{1}$ We have published results on this research previously (authors), hence, especially due to length considerations, we will concentrate on data on changes in sensemaking during the years following the crisis
} 
We followed an iterative process moving between empirical data, interpretations and theoretical frameworks (Alvesson \& Deetz, 2000, Eisenhardt \& Graebner, 2007). The data gathering included various techniques and proceeded through a series of iterative steps (see tables in appendix).

During 1996-2000 (Author) we collected data from customer advisors and customer representatives on the introduction and cultivation of sales orientation, and interviewed a strategic sample of managers in a Norwegian saving bank (Case2, Bank C, Table A.1). Data material on sales and customer interaction were further developed and analysed in 2003-2005. In 2006-2007, we conducted a comparative case study in three customer centres in Norway in a Nordic insurance company exploring the dilemmas and ambivalences in sales (table A.2).

The data covering the situation post crisis was collected between 2008 and 2014 in a strategic sample of financial institutions operating in Norway and Denmark (hence Scandinavian in the title of the paper). The sample was selected from those managers responsible for strategic or operational issues related to sales. We gathered narrative data from other managers at meetings and in-house seminars. We also made appointments with shop stewards (previously financial advisors), who play a key role within the Nordic model of industrial relations. We saw these informants discuss the impact of the crisis in various public fora, in which they were challenged to make public sense of the unfolding events in terms of their implications for employees/union members, which provided us with rich descriptions from different angles. Financial advisors were selected to cover differences in age, gender, seniority and branch/geographical location. In 2009 we collected data from union participants in a seminar on customer-orientation. 
Interviews were framed by prior documentary and web site analysis. The interviews proceeded as a dialogue (Kvale, 1996) centred on narratives of unfolding events (Czarniawska, 1997). ${ }^{2}$ The majority of the interviews lasted for 1.5 hours. Each interview concluded with the subject filling in a simple quantitative mapping survey on sales practices. We also conducted nonparticipant observations; took photographs (used as data in presentations to the firm) during guided tours by our hosts, and-as well as engaginged in informal discussions. Thus, we had ample data on the various phases of sales pre- and post crisis from the different perspectives of managers and employees (Forseth, Røyrvik \& Clegg, 2013).

In order to get viewpoints from a macro level, we interviewed four members of the Board of the Finance Sector Union of Norway, a director of the Norwegian Financial Services Employers' Association and an advisor to the Financial Supervisory Authority in Norway. We reviewed extensive documentation generated in relation to financial sales, including strategy documents, memos, performance reports, institutional self-presentations, annual reports and union members' magazines. The data also comprised public reports and clippings from business papers on sales of financial instruments, and cases launched by small savers/consumer bodies in the courts. We accessed naturally occurring data by presenting and discussing results on sales rhetoric and practices in focus groups, four workshops and seminars of managers, employees and union members in the case banks $(2007,2008,2009,2013)$, as well as a meeting at the Finance Sector Union of Norway. These were useful in validating and revising the accounts that we were forming. Through these exchanges we elaborated our interpretations and overall perspective. On this basis we exposed our ideas to further commentary at international conferences and gained valuable feedback (authors, authors). In total, we collected a considerable amount of data, collected over several years in an intensive process.

\footnotetext{
${ }^{2}$ A detailed description of data sources and interviewees are presented in table 1 and the appendix.
} 
Data analysis

The process of data analysis and interpretation proceeded iteratively (Alvesson \& Kärreman, 2011). Inspired by @Adhering to the founding principles of grounded theory (Glaser \& Strauss, 1967), the team's interpretive processes were very "hands on", coding and analysing data, both individually and in collaboration, in several rounds, before re-entering the field to collect supplementary data and validate preliminary findings. We sought to capture ante-narratives from the multiple plurivocality of accounts circulating in fragments (Billig, 1996). We generated narrative themes recurring across various categories of members, tracking changes in sensemaking, analysing them as figure against the ground of shifts in formal narration.

\section{The Brave New World of Sales}

Frontline financial service personnel advise and sell, and being a seller was celebrated before the crisis. According to the industry view, "the financial industry believes all customers realize that advisors are really sellers, but to call themselves 'sellers' will have impact on their professional pride" (Dagens Naringsliv, 6 March, 2009). One interpretation of this statement is that advisor has a more neutral and positive connotation than seller. Financial advisors were first monitored on a few performance sales indicators in the 1990s with the number of indicators increasing over time to the wide range of (sales) indicators used today. Some experienced Customer Representatives (Insurance, Team A and B, 2006) talked in a pejorative way about competitive, brazen rookies, "vacuum cleaner sellers", increasing sales by cutting corners and behaving in an unethical manner. Sales, sales, sales became the new mantra and financial instruments were a key element in the new sales culture in financial institutions. Managers tended not to dwell on the technicalities, stressing that too much technical information could make the dialogue with customers more difficult and time consuming, captured perfectly in the following: 
Our sales manager came back and was very happy after an encounter with some customers who were short on liquidity and wanted to re-finance. He had advised them to get a fixed rent serial loan, not pay any instalments, and invest their new loan in a financial instrument. This is nothing but a 'kinder-egg', he exclaimed, [referring to a children's chocolate egg with three wishes come true: a surprise, a small toy and chocolate,]. I told him, this was unethical - you cannot do this... and he was angry with me... almost harassed me, and then I was told to come to his office and he asked if I really was suitable for this job.

(Financial Advisor), Case 1, Bank A, 2008)

Financial instruments were presented as "magic" products with probable high returns for customers. Advisors were not all sanguine about this aspect of their culture: "The one-eyed sales culture made me feel uneasy", said one Financial Advisor (case 1, Bank A, 2009). 'There was a lot of pushing of products' before the crisis and little advice that if funds invested fell to a certain per cent of value, they could be terminated. Some qualms were expressed:

I warned about financial instruments - that they should be forbidden - early on. I was scolded - harassed
by my manager at an in-house meeting for having the lowest scores on investments [in financial
instruments], and accused of not understanding what we were doing. Today these products are banned -
we are not allowed to offer them any longer. (Senior Financial Advisor, Case1, Bank A, 2011)

Before the crisis, those financial advisors who resisted selling financial instruments were marginalized. As this financial advisor put it: "If it hadn't been for the crisis, these products would have yielded a high profit and gone sky high, and I would have stood there as a fool”. It turned out that he was not the only one who was unable to understand the new products that were being marketed: “...nobody had really understood this product” created by "financial acrobats" in Wall Street (McDonald \& Robinson, 2009, Tett, 2010).

\section{Phase 1: Before the jolt, in a remote corner of the global world}

A manager claimed sales should drive organizational behaviours in a competitive environment (Strategic Manager, Case 2, Bank C, 1998). Incentive schemes, performance indicators and individual coaching from team-leaders were directed towards this goal. Some employees welcomed the new sales demands as a challenge, while others were concerned about the downsides: "It has become so fixated on sales that it has gone completely to the head of the bosses ... It [the focus on sales] is compromising quality. We sit and sort out mistakes done by 
top sellers, but that is neither valued nor recorded" (Customer Representative, Insurance, team A, 2005). Other colleagues talked about unintended consequences such as mis-selling (selling inappropriate products for the customer) and over-selling (selling more product than the customer could afford). When asked in retrospect "if they had been advising customers to invest in financial instruments", one Financial Advisor replied rhetorically: "If we advised our customers? We were pressured to sell [such products]" (Financial Advisor, Case 1, Bank B, 2010).

When the GFC first jolted these organizations, the managers in our sample emphasized that “their" financial institution had good systems and attitudes to risk-taking and had pursued a conservative risk practice. They spoke of incidents where they suffered some minor losses and that they had been "lucky and clever". The sense of luck and cleverness was seen to be absent from some other financial institutions in Europe that the informants insisted had taken greater risks. Perhaps financial institutions in the Nordic countries financial institutions-were not as culpable as Wall Street and elsewhere, nor as jeopardized as institutions and experiencing a crisis of liquidity (Engelstad, 2013), but tales of Nordic financial institutions mis-selling and over-selling began to circulate in official enquiries and press reports (The Financial

Supervisory Authority, Norway, 2008). In 2009 when we raised the issues, one CEO first emphasized the importance of the demand side:

It's quite interesting this debate on over-selling - because it has two sides to it. It has a customer side because customers got very concerned about return and fancy products. You had innovative players in the market that came up with a brand new product - and loyal customers came to us and said: But look what they've got! You must be able to come up with something similar - shipping, limited partnership units in Russia - very exciting! Why don't you have something like that to offer us? If you fail to provide it, we do not bother to trade here. In a way this was half of the euphoria, right? (CEO, Case 1, Bank A, 2008)

Demand from wealthy customers and fear of losing out in the competitive race created a demand for the new financial instruments. The other side of the coin was the supply side: 
The other half, it's nothing to hold back - this was a very profitable product and the bank was very geared to selling it. In sum, it was such a cocktail that is like most cocktails: Gives a slight hangover after some time. But I think it was also a picture of a Norwegian economy really booming, rather than Norwegian banks sitting in the driver's seat and sort of pushing their customers. (CEO, Case 1, Bank A, 2008)

Although this manager admitted that the bank profited from the financial instruments and talked about the times before the crisis as "bit of a party", he underscored the importance of external factors driving behaviour such as the "booming economy" and then the "biggest downturn in the U. S. since 1929-30". The bank had offered financial instruments on the premise of a low risk profile but there is always a risk with any product, he added. To underscore his argument he elaborated how one of the senior managers was one of the largest buyers, who would not have invested that much "if he had known that this was a shitty deal, right?"--The manager also introduced the the-metaphor of a "cocktail" to characterize the situation. Cocktails can be delicious, but they can also cause a hangover.

It was not only managers who exhibited wilful blindness and did denial, according to one shop steward (Case 1, Bank B, 2011): he claimed that many customers knew what they were doing with their dreams of easy money. Denial and surprise after the financial crisis were nothing but retrospective rationalizations, he suggested: customers sought to avoid appearing fools.

Managers and financial advisors alike underscored how investors who bought early were smart and experienced, earning a profit. It was when they started selling financial instruments to " $\mathrm{Mr}$ and Mrs Jones" that things really went wrong, because they could not afford to loose their money (Case 1, Bank A, 2010).

After the crisis it was easy to use advisors as scapegoats. In his defence one financial advisor noted that he was only doing what corporate sales strategies required: was it his fault if he was respectful of the moral order that prevailed in the culture? "It [financial instrument] was regarded as a top product. We [advisors] are being blamed for not having thorough knowledge. We trusted back-office [who said that this was]: a superb product. Is this mis-selling or being a 
‘cowboy'?” (Financial advisor, Case 1, Bank A, 2010). From managers and employees alike we heard accounts of individual co-workers labelled "cowboys": cheeky, brazen, competitive individuals, who were motivated by bonuses that, especially in the private banking sector, could double their salary through successful sales of these financial instruments. One shop steward (Case 2, Bank C, 2012) underscored that it was easy to blame financial advisors when it was management that jumped on the bandwagon and forced the employees to sell, yet managed to evade responsibility. Individual team-leaders and sales managers were also scapegoated:

... Everyone knows that if you stand and hold a carrot in front of a runner, he runs even faster for a period. It works in the short term, but not in the long term. When it turned into over-selling and misselling I think there were managers - often management that had an overly short-term focus.

(Human Resources Manager, Case 2, Bank D, 2010)

One financial advisor told us that just before the crisis a 'cowboy' sales manager was hired who cultivated an aggressive sales culture (Case 1, Bank A, 2008). Sales managers had to rank their staff's effort, highlighting advisors' scores on sales and investment. Results were displayed. Normalization, the arrangement of performance outcomes in a graphical form, is a powerful technology of control: the positive outliers are a positive example to all and negative outliers a stigma. Managers admitted that using such visualizations of key performance indicators was one of the strategies encouraging what became known as mis-selling. One manager said: "We had a sales culture cheering good sales. Who were then responsible for customers having bad experiences dealing with us? The financial advisor who sold the product or the employer who organized the incentives and cultivated a culture?" (Human Resources Manager, Case 2, Bank C, 2012)

In the past, bankers had been socialized within a "credit culture" where the "sexiest thing in the world is a spread-sheet" (Vice President Sales, Case 1, 2011). Maintaining bank and individual account credit balances was crucial. Over time, metrics for the number and amount of loans, the 
number and volume of savings (investments), number and volume of insurance, referrals to insurance, referring customers to the mortgage brokerage department, were added as kpi's. Measuring outcomes encouraged focusing on selling as a process (Case 1, Bank A, 2011). The number of scheduled customer encounters became an important figure. Discussing sales strategies at a trade union seminar in 2009 , financial advisors complained that they felt this constant monitoring was a violation of their professionalism, yet their managers claimed it was necessary in order to keep them sales-focused. The industry became increasingly oriented towards innovating and selling new financial products.

\section{Phase 2: After the jolt, a period of re-orientation and a shift to "right selling"}

The crisis was a significant jolt for Nordic financial institutions: even if profitable, they had to cope with a tarnished image characterised by what became known as mis-selling and overselling. One headline on Case 2, Bank C from our sample of media clippings read like this: "Financial instruments sold to 80 year old lady with dementia" (Business paper Dagens Naringsliv, 12 February 2009). Case banks, as well as other Nordic players, received much negative media coverage regarding small savers' cases taken to court by consumer bodies.

Financial institutions rely on European directives, the Basel accords, as well as the Markets in Financial Instruments Directives (MIFID), a European Union law from 2007 harmonising the regulation of investment services across member states. Even though Norway (in contrast to Denmark and Sweden) is not a member of the EU, the country aligns itself with these imperatives. Additionally, instead of waiting for the authorities to impose new regulation, the industry had started to certify financial advisors in order to work on the sales culture proactively. Financial advisors in Norway had to pass a comprehensive, written exam including questions about derivatives and ethics, as well as a practical test in which the candidate has to plan, interact with a 'customer', and provide oral and written documentation. 
Armed with the new insight that the changed regulatory environment provided, one manager concluded that

The downsides of the sales culture came to the fore - we had sold [financial instruments] to customers who should never have invested in them, or provided advice based on an incentive model founded on how to optimize [the advisors'] wallet rather than the profitability of the customer. (Human Resources Manager, Case 2, Bank C, 2012)

Increased corporate self-awareness led managers to distance themselves from earlier accounts shirking responsibility.

One aspect has been to sort out cases of mis-selling where we were involved - we still do... Then it was time to look at incentives - because we had a sales culture praising high sales ... and we were the architects behind the incentive system. (Human Resources Manager, Case 2, Bank C, 2012)

The sensemaking shifted from externalization and individualization to consideration of their role as 'architects' of incentive schemes and sales cultures.

Now, it's not just about selling, but 'right selling'. You are not clever if you over-sell. You have to know the products in detail... You have to pull them apart - that is why it is not easy to be good at this.

(Financial Advisor, Case 1, Bank A, 2010)

After the crisis jolted the culture and its ideology of sales, the image of the super seller was downplayed and the image of a service-oriented advisor celebrated. Other financial advisors noted, however that "it is not as simple as shift to 'right-selling', there is just as much pushing [of products] now" (Financial Advisor, Case1, Bank B, 2010). "Right selling" (matching sales products to customer requirements, income and investment profile), was emphasised by employees, trade union representatives and managers in stark contrast to the pre-crisis period when "big packages of products were thrown at the customers", to quote a Shop Steward (Case 1, Bank B, 2011). A financial advisor elaborated on these changes:

Now there is more focus on being advisor in the sales of saving products. We are done selling big packages [of complex financial products]. Our primary mission is no longer sales [sic]... now it is teamrelated bonuses and a focus on sales and satisfied customers. (Financial Advisor, Case 1, Bank A, 2010)

In the readjustment phase after the GFC, a manager spelled out their new strategy: 
On the strategic level we have defined the $4 \mathrm{C}$ 's: Customer, credit, costs and capital. We talk about customers as the capital $\mathrm{C}$, and emphasize that this is very important and that we have a vision about becoming the most customer oriented bank in the Nordic countries. (Vice President, Case 1, Bank B, 2010)

Customers were celebrated as "capital C" discursively. Corporate rhetoric sought to increase trust while still improving competitive edge. On webpages and in commercial campaigns finance houses claimed that they excelled in the "art of customer care" (bank web-site). Informants explained to us that "we behave like gregarious animals and copy what the others do" (Manager, Case 2, Bank C, 2011), in terms of products, concepts and slogans. Isomorphism is rife.

Not all industry insiders were enamoured of the new rhetoric. One banker said: "We have never been customer oriented” (Manager ICT, Case 2, Bank C, 2011). Others claimed they had always been concerned with reputation and image. One financial advisor claimed his behaviour towards customers after the GFC had not changed because he had been customer oriented all along. Renewed interest in customer orientation was mostly corporate rhetoric, he said, a view colloquially supported by a shop steward as a way of "covering their ass" (Case 1, Bank B, 2011).

Financial advisors agreed in response to an email survey prior to a union seminar, that "We still have a long way to go before every part of the bank is customer-oriented". The rhetoric was widely circulated, however. One top-level manager sought to convince us that after the GFC customer satisfaction was the only important indicator for monitoring encounters with financial advisors. Despite these claims, often couched in seductive rhetoric in corporate brochures, subsequently we found other parameters being monitored. A wide range of key performance indicators believed to contribute to increased performance and sales were still measured: "We monitor our employees on too many dimensions - we have not cleaned up well in this respect. 
If it was up to me, we would only measure three to four things" (Vice President, Case 1, Bank B, 2010).

A customer orientation, promoted as a shift to more "right selling", resulted in new performance indicators related to "the moment of truth" - as one bank labelled the interaction with customers. These gave the individual advisor feedback on performance, measured in terms of customer satisfaction with the encounter, providing management rank orders of customers' satisfaction with encounters. "Management by customers" (Fuller \& Smith, 1991) translated into enhanced surveillance and disciplinary control of those low on the distributional curve of customer satisfaction. Customer satisfaction can be affected by an infinite number of variables, such as the identities attributed to the bank officer (male/female; young/old; black/white; attractive/unattractive, native/non-native, etc.) and the outcome of the visit (approval or denial of loan). For any number of reasons an officer might be perceived as a negative outlier in normal distribution used to stigmatize the tail.

\section{Discussion}

We have used examples of organizational storytelling to chart the transition from a world celebrating sales to its opprobrium and strategic repair work. The theoretical concept of environmental jolt captures the unexpected, unplanned and uncertainty inducing ( ), and might contribute to biased interpretation in the direction of a natural catastrophe that is not man-made.

Some of our informants compared the crisis to a tsunami with dramatic, overall changes outside the control of incumbents in the financial industry. First, we might indeed question how unexpected the financial crisis was, as some informants admitted there were warning signs. Second, politicians and regulators made changes to regulation acts and lay the ground for de regulation and the increased financialization.We investigated significant shifts legitimating financial sales practices as well as the emergence of new strategies for re-orientation and new 
standards for sales. Meyer (1982) underscored jolts as occasions for overall strategic change, illustrating how managers celebrated existing ideologies in their responses to jolts, as we found in the first phase-. Accounts subsequently changed longitudinally after the jolt. Our data reveals managers' re-framing and reconsidering accounts of strategies and practices andfrom which $\mathrm{w}=$ We identified common patterns in tTheir accounts had some common themes,. ? $\underline{\text { ?but }}$ they also differed according to level and position within the institutions. We illustrated how financial advisors and union representatives were more critical of the enhanced pressure to sell. Accounts-subsequently changed longitudinally after the jolt. Our data reveals managers' re-

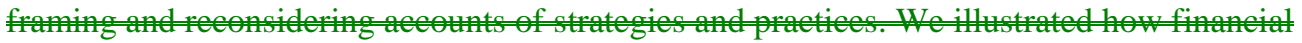
alvisors and union representatives were more-critical $\theta$ f the enhanced pressure to-sell.

As Maclean et al. (2012) note, stories about failure differ markedly from those of success. Failure is accompanied by attributions of blame. Financial managers initially played a blame game regarding sales practices, making excuses, simplifying temporal changes, dramatizing external factors, events and people as responsible, deemphasizing corporate strategies and practices. Blame and responsibility were attributed to others rather than accepting personal responsibility. Booming economies, critical timing, and single actors were emphasized rather than the complex interplay of a network of actors and factors. The immediate post-GFC rhetoric celebrated existing financial sales ideologies and practices and contradicted any critical voices coming from front line operations.

As the effects of the crisis unfolded, practices of mis-selling and malpractice were revealed. Initially, financial institutions scapegoated individual financial advisors and sales managers - 
labelled "cowboys". Later, the role of incentive schemes, sales practices and to some extent, strategies, were acknowledged. The GFC jolted interpretive horizons leading to more selfreflexive and critical views of aggressive sales practices and alchemic financial instruments. Managers now recognized a 'culture of greed' (cf. Madrick, 2011) had developed and that incentive schemes and other strategies aimed at cultivating enhanced sales were responsible. Not only did differently situated actions generate different vocabularies of motive (Mills, 1940); differently situated agents did so as well (Whittle and Mueller, 2012). A complex morality play emerged in which initially it was the jolt itself that was blamed, then agencies less remote and more identifiable as knowledge of organizational practices was increasingly made public.

In a second response managers used what we term conceptual plurivocality, with multiple interpretations (Thatchenkery, 1992) infusing new meaning into old concepts, particularly customer orientation. In the 90s, this term was related to the "inward-oriented" organization of services (what was convenient for the bank rather than the customers) (Manager, Case 2, Bank C, 1999). In the period prior to the GFC the focus was on notions such as "shareholder value" and "value based management" (Røyrvik 2011) offering profit for both customers and shareholders. In the aftermath of the crisis, the notion of customer orientation was transformed, increasingly being used as a catchword to describe changes in (sales) practices. Some financial advisors were critical towards the new customer turn, claiming it was mostly rhetoric. One of them-said that he had been customer-oriented all along; and athat proof of this was that he had refused to sell financial instruments to his customers before the crisis. Today the needs of the customer are positioned as a pivotal concern open to flexible interpretation ${ }_{-2}^{3}-$ Customer need is not fixed but context dependent, varying both among different customers and from situation to situation. These needs are co-created by financial advisors, operating according to varying

${ }^{3}$ Respondents initially largely asserted customer service had been their prime concern all along, even before the GFC. Only one banker that we encountered expressed doubts that this was the case. 
banking concepts and a concern with the most profitable customers. Customer orientation comprises a conceptual plurivocality providing meaningful flexibility with room for strategic and rhetorical manoeuvring across all three stages. Initially, respondents asserted customer service had, all along, largely been their prime concern, even before the GFC. We encountered only one banker exprssing doubts that this was the case.

Finally, we introduced examples that demonstrate the third response, which we labelled embellishment, due to significant shifts that occurred in legitimating financial sales practices as well as the emergence of new strategies for re-furbishing brand image to regain customer trust. After the onset of the GFC, the new concept of "right selling", as opposed to what became known as "mis-selling", was introduced to demonstrate a new era had begun. Before the GFC, the emphasis was on incentives schemes directed to sales, whereas afterwards the advisor role was celebrated. One manifestation was the creation of a programme of training for financial advisors presented as evidence of an enhanced concern with ethics in sales and greater awareness of the needs of the customers. The programme was a way of legitimating a new ideology and of de-legitimating that associated with the crisis, yet, at the same time, managers underscored that all advisors are sellers and that cash-back or payback remains the underlying expectation. The changes targeted major shifts in brand and image, largely through rhetorical devices, while in practice little changed.

In the introduction we spelled out three important paralletchanges that took place after the deregulation of the financial industry, although not in parallel at exactly the same time and in the same way in every local branch/context: Thecal knowledge was increasingly displaced by technical competence with computer programmes, aggressive selling tactics and a more meritocratic ethos characterized the new ethos. We found the same elements in our material, yet ilt was the changes in the sales cultures in a more aggressive direction that were most 
salient.This, which may not be too surprising given the relatively peripheral position of our cases in terms of creating, rather than "just selling", the controversial financial products. The articleOur material also documents how selling practices and rhetoric related to sales changed again as an effect of the GFC jolt. In campaigns to refurbish their image, regulation and new ethical standards of selling were introduced, although we rather surprisingly found that the pressure to sell did not decrease.:

-The theoretical concept of environmental jolt has connotation to a natural catastrophe with fundamental changes and re-structuring. In line with this, it was interesting to note how managers and employeesy informants talked about the coming of the crisis as a tsunami with dramatic and global changes outside the control of incumbents in the financial industry. Some told us there were warning signs; but many informants still claimed that the crisis was unexpected. The crisis a resulted from of anthe interplay of manyseverat factors, especially those that butWall Street bankers had invented the financial instruments that propelledwere networked world-wide and contributed to the crash. Our informants did not loose their jobs as did their colleagues in the banks that went baenkeruptin Lehman Brothers, but they had to cope with some of the consequences of the crisis. -It alse-struck us that that it was difficult to grasp and make sense of the exact effects and changes post crisis. First, there were rather small changes over time rather than one revolutionary change post crisis. Second, the jolt manifested itself in different ways in local contexts, and the accounts differed according to level and position within the institutions. We illustrated how financial advisors and union representatives were more critical of the enhanced pressure to sell. there were differences in responses e.g. eontributed to For some financial advisors in small, local branches, the events at Wall $\underline{\text { Street seemed far away from their everyday workday; in their view , and-they had just been }}$ doing their job, even if it involved offering complex financial products "at low risk". Post crisis, informant admitted the conception of risk was much more complex and difficult to grasp. 
Secondly, compiling the accounts of our informants resulted in a complex and sometimes contradictory picture and it was difficult it was a challenge for us to sort outdistinguish between actual changes and rhetoric about the changes. : at one instant we were told that after the crisis, eustomer satisfaction about changes.

We have described how Iincreased regulation from the authorities contributed to new demands for financial advisors and and-financial institutions alike,,- butalbeit that these regulations have been termed-were modest (Løyning 2014-sos_-). Besides, and how a system of authorization of financial advisors developed from within the financial industry, focusing on rewriting. "right selling", ethics -and new practices. For the employees, however, the new positive customer orientation has not reduced the pressure to sell but has contributed to intensification of their work, producing more paperwork through enhanced reporting and documentation. Enhanced monitoring and disciplinary control is camouflaged by the shift to a customer orientation. Mapping customer satisfaction is now added to existing performance parameters related to products and sales, illustrating the ambivalence of a concept presented as a proof of a positive development. The cult(ure) of the customer and the discourse of enterprise (Miller \& Rose, 1997, du Gay \& Salaman, 1992) characterize the turn to customer orientation. The increased discipline, monitoring and control of advisors through record-keeping means there is 
actually less time to spend talking to customers, even if the customer is said to be pivotal, customer-orientation the guiding light, and customer satisfaction the metric. To sum up, the crisis manifested itself differently in various local contexts that were far from the epicentre of the jolt. Thus, there is not one single diagnosis that applies to all the sites that we researched. There was no revolutionary change; but small changes that sought in order to rebuild image and trust in the sales practices and the financial institutions.

\section{Change and continuity refer to sentence}

\section{+1 setn til concl!}

\section{Conclusions}

The tacit rules of the financial services game became much more evident as a result of the GFC breaching what had become expectations of normal business practices. An unfolding event, it jolted what had become the ideological basis of business as usual. After the jolt was recognised managers initially externalized blame, making excuses that enrolled other actors and factors in their account_s making use of simplification in their account of sales and the crisis. They did so by making use of simplifications and - we think of this process as the construction of a blame game. Leaders near the epicentre of a jolt typically do this (Reinhardt \& Rogoff, 2009; Palma, 2009). Secondly, they practised conceptual plurivocality by infusing old concepts with new

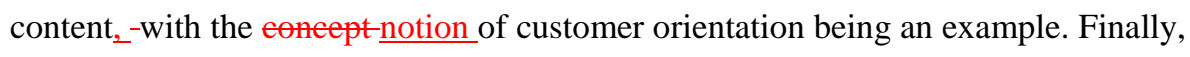
embellishment shows managers introducing new measures, rhetorical figures, sales strategies and practices as responses to the jolt to prove that an era of right selling had begun, one which translated into enhanced surveillance and disciplinary control of employees, albeit not explicitly acknowledged as such. 
AThe accounts of the impacts of the crisis differed according to level and position within the institutions. We illustrated how financial advisors and union representatives were more critical of the enhanced pressure to sell and emphasized how the turn to right-selling and re-orientation post crisis involved some actual changes but also rhetoric and "newspeak". Revolutionary changes were as hard to depictfew and far between in a context, it was rather a question-of piece-meal changes and modest regulation.

The theoretical contribution of this paper is to show how, recursively, jolts threatened local legitimations of management practice and became the occasion for creative sensemaking that rationalized failure, apportioned responsibility and maintained legitimation, whilst simultaneously deepening existing disciplinary measures under cover of a new rhetoric of the customer. While earlier accounts of jolts by Meyer (1982) saw them as occasions for overall strategic change by organizations, we have investigated everyday practices unfolding over time, far removed from moments of strategy formulation, in order to grasp the nature of adaptation to jolts. Jolts disrupt everyday routinized processes and require members to develop new accounts of their practices as existing accounts are delegitimized. To the extent that jolts create strategic opportunities, these become materialized through everyday discourses as practices of evolving sensemaking.

Add one sentence or two

\section{Acknowledgements}

Thanks to Tove Håpnes for data collection and previous analysis, and feedback from informants and stakeholders in finance. 


\section{Funding}

We are grateful for support from: The Research Council of Norway (RCN), 2008-2011[grant no. 185055/S20], The Norwegian University of Science and Technology, and previous funding from the RCN, 1996-2001 [grant no. 109175/330], 2003-2005 [grant no. 156076/510] and an insurance company, 2006-2007.

\section{References}

Alexander K., Dhumale R., \& Eatwell J. (2005). Global governance of financial systems: The international regulation of systemic risk. New York: Oxford University Press.

Alvesson, M., \& Deetz, S. (2000). Doing critical management research. London: Sage.

Alvesson, M., \& Kärreman D. (2011). Qualitative research and theory development. London: Sage.

Arrighi, G. (1994). The long twentieth century: Money, power and the origins of our times. London and New York: Verso.

Berge, L., Forseth, U., \& Håpnes, T. (2009). Salg, salg, salg... - Om mestringsstrategier og arbeidsstiler i salg av forsikringer [Sales, Sales, Sales... - Coping Strategies and Work Styles in the Selling of Insurance], Sosiologisk tidsskrift, 17 (3), 195-216.

Billig, M. (1996). Arguing and thinking: A rhetorical approach in social psychology. Cambridge: Cambridge University Press. 
Clegg, S., Carter, C., Kornberger, M., \& Schweitzer, J. (2011). Strategy: Theory \& practice. London: Sage.

Courpasson, D. (2006). Soft constraint, liberal organization and domination. Chapter 5. Copenhagen: Liber and Copenhagen Business School.

Czarniawska, B. (1997). Narrating the Organization. Dramas of Institutional Identity. Chicago and London: The University of Chicago Press.

Du Gay, P., \& Salaman, G. (1992). The Cult(ure) of the customer. Journal of Management Studies, 29 (5), 615-633.

Duménil, G., \& Levy, D. (2004). Capital resurgent: Roots of the neoliberal revolution. Cambridge, MA: Harvard University Press.

Eisenhardt, K.M., \& Graebner, M.E. (2007). Theory building from cases: Opportunities and challenges. Academy of Management Journal, 50 (1), 25-32.

Engelstad, F. (2013) Responses to the financial crisis. Institutions, elite negotiations and the vulnerability of democracy. Paper presented at the Åsgårdstrand Conference on institutional change in welfare state and working life, Norway, 11-12 June.

Epstein, G.A. (ed.) (2005). Financialization and the world economy. Cheltenham: Edward Elgar.

Flyvberg, B., Landman, T. \& Schram, S. (2012). Real social science. Applied phronesis. Cambridge: Cambridge University Press. 
Forseth, U. (2001). Boundless work - Emotional labour and emotional exhaustion in interactive service work. Dr.Polit. Dissertation, Norwegian University of Science and Technology, Trondheim.

Forseth, U., Røyrvik, E.A., \& Clegg, S.R. (2013). 'Heroes and Villains - Bankers narratives after the global financial crisis. Paper presented at the $29^{\text {th }}$ European Group for Organizational Studies (EGOS), July 4-6, Montréal, Canada.

Forseth, U., Clegg, S. R. \& Røyrvik, E. A. (2014). "The moment of truth”: Valuation devices to promote customer orientation and 'right selling' in finance. Paper presented at the $5^{\text {th }}$ LAEMOS Colloquium, April 2-5, 2014, Havana, Cuba.

Foster, J.B., \& Magdoff, F. (2009). The great financial crisis: Causes and consequence. New York, NY: Monthly Review Press.

Fuller, L., \& Smith, V. (1991). Consumers' reports: Management by customers in a changing economy. Work, Employment \& Society, 5 (1), 1-16.

Galbraith, J.K. (1954). The great crash of 1929. Boston: Houghton Mifflin.

Glaser, B., \& Strauss, A. (1967). The discovery of grounded theory. Chicago: Aldine.

Harvey, D. (2005). A brief history of neoliberalism. Oxford and New York: Oxford University Press.

Ho, K. (2009). Liquidated: An ethnography of Wall Street. Durham and London: Duke University Press.

Korczynski, M. \& Ott, U. (2005). Sales work under marketization. The social relations of the cash nexus. Organization studies, 25 (5), 707-728. 
Knights, D. \& Tullberg, M. (2011). Managing masculinity/mismanaging the corporation. Organization, 19 (4), 385-404.

Knights, D. \& McCabe, D. (2014). 'We're sticking around': Demystifying leadership in the context of the global financial crisis of 2008. Paper, Retrieved October, 24, 2014, from https://www.academia.edu

Krugman, P. (2007). Innovating our way to financial crisis. The New York Times, December 3, 2007. Retrieved May 19, 2011, from http://www.nytimes.com/2007/12/03/opinion/03krugman.html

Kvale, S. (1996). InterViews. Thousand Oaks, London: Sage.

Leopold, L. (2009). The looting of America: How Wall Street's game of fantasy finance destroyed our jobs, pensions and prosperity - and what we can do about it. White River Jct, VT: Chelsea Green.

Maclean, M., Harvey, C., \& Chia, R. (2012). Sensemaking, storytelling and the legitimization of elite business careers. Human Relations, 65 (1), 17-40.

Madrick, J. (2011). Age of greed: The triumph of finance and the decline of America, 1970 to the present. New York: Alfred A. Knopf.

McDonald, L. \& Robinson, P. (2009). A colossal failure of common sense: The inside story of the collapse of Lehman Brothers. London: Ebury Press.

McDowell, L. (1997). Capital culture. Gender ay work in the city. Oxford: Blackwell Press. 
McKinlay, A., \& Quinn, B. (2007). Remaking management, work and industrial relations: British commercial television, c. 1979-2000. Historical Studies in Industrial Relations, $23 / 24,155-180$.

McKinlay, A., \& Wilson, R.G. (2006). 'Small acts of cunning': Bureaucracy, inspection and the career, c. 1890-1914, Critical Perspectives on Accounting, 17 (5), 657-678.

McKinlay, A. (2013). Banking, bureaucracy and the career: the curious case of Mr Notman. Business History, 55 (3), 431-447.

Meyer, A.D. (1982). Adapting to environmental jolts. Administrative Science Quarterly, 27 (4), 515-537.

Miller, P. \& Rose, N. (1997) Mobilising the customer: assembling the subject of consumption. Theory, Culture and Society, 14 (1), 1-36.

Mills, C.W. (1940). Situated actions and vocabularies of motive. American Sociological Review, V: 904-9 13,

Ouroussoff, A. (2010). Wall Street at War: The Secret Struggle for the Global Economy. Cambridge: Polity Press.

Palma, J.G. (2009). The Revenge of the market on the rentiers: Why neo-liberal reports of the end of history turned out to be premature. Cambridge Journal of Economics, 33 (4), 829-869.

Perrow , C. (2010). The meltdown was not an accident. In Lounsbury, M. \& Hirsch, P. M. (Eds.) Markets on trial: The economic sociology of the U.S. financial crisis. Bingley: Emerald. 
Regini, M., Kitay, J., \& Baethge, M. (Eds.) (2000). From tellers to sellers: Changing employment relations in banks. Cambridge, MA: MIT Press.

Reinhardt, C. M., \& Rogoff, K. S. (2009). This time is different: Eight centuries of financial folly. Princeton and Oxford: Princeton University Press.

Roubini, N., \& Mihm, S. (2010). Crisis economics - A crash course in the future of finance. London and New York: Penguin Books.

Røyrvik, E. A. (2011). The allure of capitalism - An ethnography of management and the global economy in crisis. New York and Oxford: Berghahn Books.

Schinasi, G. J. (2005). Safeguarding financial stability: Theory and practice. Washington, DC: International Monetary Fund.

Stiglitz, J. (2009). Freefall - Free markets and the sinking of the global economy. London and New York: Penguin Books.

Sweezy, P.M. (1994). Monopoly capitalism, in Eatwell J., Milgate M., and Newman P. (Eds.), The New Palgrave dictionary of economics. London: Palgrave Macmillan.

Tett, G. (2010). Fool's gold. London: Abacus.

Thatchenkery, T. (1992). Organizations as "texts": Hermeneutics as a model for understanding organizational change. Research in Organizational Change and Development, 6, 197233.

The Consumer Council of Norway (2012). Rydd opp i sparemarkedet! Forbrukerrådets undersøkelse av finansielle rådgivningstjenester [Clean up in the Savings Market!]. Report, February, Oslo. 
The Financial Supervisory Authority of Norway (2008). Unders $\phi$ kelse av sammensatte produkter [Investigation of Complex Products]. Retrieved December 12, 2011, from http://www.finanstilsynet.no/archive/stab_pdf/01/04/03012046.pdf

The Financial Supervisory Authority of Norway (2008 - 2013). Arsmeldinger [Annual Reports].

The Financial Supervisory Authority of Norway (2014). Finansielt utsyn [Financial Outlook].

Whittle, A., \& Mueller, F. (2011). Bankers in the dock: Moral storytelling in action. Human Relations, 65(1), 111-139.

Zúniga-Vicente, J. A., De la Fuente-Sabaté, J. M. \& Suárez-González, I. (2005) Facilitating and inhbiting factors behind strategic change: Evidence in the Spanish private banking industry, 1983-1997. Scand. J. Mgmt. 21(3), 235-265.

\section{Appendices}

\begin{tabular}{|c|c|c|c|c|}
\hline $\begin{array}{l}\text { Interaction with } \\
\text { the field }\end{array}$ & Size & Topic & $\begin{array}{l}\text { Empirical } \\
\text { material }\end{array}$ & Analysis \\
\hline $\begin{array}{l}\text { Meetings with } \\
\text { management, trade- } \\
\text { union and in-house } \\
\text { seminars }\end{array}$ & $\begin{array}{l}10 \text { occasions varying } \\
\text { from } 3 \text { to } 100 \text { persons }\end{array}$ & \multirow[t]{2}{*}{$\begin{array}{l}\text { Organization of work, } \\
\text { job demands, sales } \\
\text { strategies, incentive } \\
\text { schemes, customer } \\
\text { interaction, health } \\
\text { outcomes }\end{array}$} & $\begin{array}{l}\text { Presentations, } \\
\text { field notes }\end{array}$ & $\begin{array}{l}\text { Data gathering, } \\
\text { context, check for } \\
\text { resonance and } \\
\text { relevance, } \\
\text { reinterpretation of } \\
\text { data material }\end{array}$ \\
\hline $\begin{array}{l}\text { Face-to-face } \\
\text { interviews }\end{array}$ & $\begin{array}{l}\text { Managers at strategic } \\
\text { level (2), Manager } \\
\text { Retail Division, } \\
\text { Branch Manager (2) }\end{array}$ & & $\begin{array}{l}\text { Written notes. } \\
\text { Document with } \\
\text { selected quotes }\end{array}$ & \multirow{4}{*}{$\begin{array}{l}\text { Looking for } \\
\text { patterns, } \\
\text { anomalies, the } \\
\text { empirical material } \\
\text { has been coded and } \\
\text { categorized, } \\
\text { discussed with } \\
\text { involved parties, } \\
\text { recoded and } \\
\text { reinterpreted. } \\
\text { Quantitative data } \\
\text { used as background } \\
\text { material, and open- } \\
\text { ended questions }\end{array}$} \\
\hline Observation & $\begin{array}{l}5 \text { premises, } 3 \text { visits to } \\
\text { one team }\end{array}$ & $\begin{array}{l}\text { Organization, physical } \\
\text { layout, informal talk }\end{array}$ & Field notes & \\
\hline $\begin{array}{l}\text { Quantitative } \\
\text { mapping }\end{array}$ & $\begin{array}{l}\text { Survey in Norwegian } \\
\text { saving bank: customer } \\
\text { advisors and repre- } \\
\text { sentatives }(\mathrm{N}=130) \text {, } \\
\text { managers }(\mathrm{N}=19)\end{array}$ & $\begin{array}{l}\text { Transformation of } \\
\text { work, job demands, } \\
\text { sales, customer } \\
\text { interactions, health } \\
\text { outcomes }\end{array}$ & $\begin{array}{l}\text { Data files. } \\
\text { Verbatim } \\
\text { transcription of } \\
\text { open ended } \\
\text { questions }\end{array}$ & \\
\hline Focus group & $\begin{array}{l}8 \text { customer advisors } \\
\text { and customer repre- } \\
\text { sentatives }\end{array}$ & $\begin{array}{l}\text { Sales, pleasures and } \\
\text { pains of customer } \\
\text { interaction }\end{array}$ & $\begin{array}{l}\text { Written stories, } \\
\text { audio files and } \\
\text { notes }\end{array}$ & \\
\hline
\end{tabular}




\begin{tabular}{|l|l|l|l|l|}
\hline Written narratives & $\begin{array}{l}\text { Customer advisors/ } \\
\text { representatives (155) }\end{array}$ & $\begin{array}{l}\text { Sales, pleasures and } \\
\text { pains of customer } \\
\text { interaction }\end{array}$ & $\begin{array}{l}\text { Texts. Tables } \\
\text { for content } \\
\text { analysis }\end{array}$ & used as quotes. \\
\hline
\end{tabular}

Table A.1 Overview over empirical material and methods, Norwegian saving bank (Case 2, Bank C), 1996-2001. 


\begin{tabular}{|c|c|c|c|c|}
\hline $\begin{array}{l}\text { Interaction with the } \\
\text { field }\end{array}$ & Size & Topic & $\begin{array}{l}\text { Empirical } \\
\text { material }\end{array}$ & Analysis \\
\hline $\begin{array}{l}\text { Meetings with union \& } \\
\text { management, in-house } \\
\text { seminars }\end{array}$ & $\begin{array}{l}8 \text { occasions varying } \\
\text { from } 4 \text { to } 20 \text { persons }\end{array}$ & \multirow{2}{*}{$\begin{array}{l}\text { Organization of work, } \\
\text { job demands, sales } \\
\text { strategies and practices, } \\
\text { incentives schemes, } \\
\text { performance indicators }\end{array}$} & $\begin{array}{l}\text { Presentations, } \\
\text { field notes }\end{array}$ & \multirow{4}{*}{$\begin{array}{l}\text { Data gathering, } \\
\text { context, check } \\
\text { for resonance } \\
\text { and relevance, } \\
\text { reinterpretation } \\
\text { of data material }\end{array}$} \\
\hline $\begin{array}{l}\text { Face-to-face } \\
\text { interviews }\end{array}$ & $\begin{array}{l}\text { Regional Managers } \\
\text { (3), Team Leaders } \\
\text { (4), Customer } \\
\text { reps./sellers (29) }\end{array}$ & & $\begin{array}{l}\text { Written notes, } \\
\text { sound files, } \\
\text { document with } \\
\text { quotes }\end{array}$ & \\
\hline Observation & $\begin{array}{l}10 \text { visits, } 2-3 \text { days at } \\
3 \text { customer centres, } 3 \\
\text { regions in Norway }\end{array}$ & $\begin{array}{l}\text { Organization, physical } \\
\text { layout, informal talk }\end{array}$ & $\begin{array}{l}\text { Photographs } \\
\text { Field notes }\end{array}$ & \\
\hline Quantitative mapping & 36 & $\begin{array}{l}\text { Sales goals vs. } \\
\text { practices: seller skills, } \\
\text { customer orientation, } \\
\text { performance etc. }\end{array}$ & $\begin{array}{l}\text { Excel charts, } \\
\text { numbers. } \\
\text { Comparison } \\
\text { between teams } \\
\text { and regions }\end{array}$ & \\
\hline Written narratives & 5 & $\begin{array}{l}\text { Episodes of team- } \\
\text { leader and employee- } \\
\text { driven strategies to } \\
\text { enhance sales }\end{array}$ & $\begin{array}{l}\text { Texts. Tables } \\
\text { for content } \\
\text { analysis }\end{array}$ & $\begin{array}{l}\text { Dilemmas in } \\
\text { sales/customer } \\
\text { interactions. } \\
\text { Disciplination, } \\
\text { employee vs. } \\
\text { manager-driven } \\
\text { performance }\end{array}$ \\
\hline Internal documents & 300 pages & $\begin{array}{l}\text { Institutional self- } \\
\text { presentations, sales } \\
\text { strategies, performance } \\
\text { health outcomes }\end{array}$ & $\begin{array}{l}\text { Memos, } \\
\text { reports, } \\
\text { presentations, } \\
\text { statistics }\end{array}$ & $\begin{array}{l}\text { Background } \\
\text { material } \\
\text { informing data } \\
\text { gathering, } \\
\text { checked for } \\
\text { consistency w. } \\
\text { interpretations }\end{array}$ \\
\hline
\end{tabular}

Table A.2 Overview over empirical material and methods, Nordic Insurance Company, 2006-2007. 


\begin{tabular}{|c|c|c|c|c|}
\hline $\begin{array}{l}\text { Interaction with the } \\
\text { field }\end{array}$ & Size & Topic & $\begin{array}{l}\text { Empirical } \\
\text { material }\end{array}$ & Analysis \\
\hline Public documents & 950 pages & \multirow[t]{2}{*}{$\begin{array}{l}\text { Context data, sales } \\
\text { strategies, } \\
\text { performance, } \\
\text { incentive schemes, } \\
\text { financial instruments, } \\
\text { the crisis, impacts, } \\
\text { reputation, legal court } \\
\text { cases, regulation }\end{array}$} & $\begin{array}{l}\text { Web sites, } \\
\text { commercial } \\
\text { campaigns, } \\
\text { media } \\
\text { clippings, } \\
\text { trade union } \\
\text { magazines }\end{array}$ & $\begin{array}{l}\text { Used as context data } \\
\text { and input to } \\
\text { formulation of } \\
\text { interview guide and } \\
\text { analysis }\end{array}$ \\
\hline $\begin{array}{l}\text { Meetings/seminars with } \\
\text { management, trade } \\
\text { union members, } \\
\text { employees in-house, } \\
\text { conferences industry }\end{array}$ & $\begin{array}{l}8 \text { occasions } \\
\text { attendees } \\
\text { varying from } 3 \\
\text { to } 50 \text { persons }\end{array}$ & & $\begin{array}{l}\text { Presentations, } \\
\text { audio } \\
\text { recording, } \\
\text { field notes }\end{array}$ & $\begin{array}{l}\text { Data gathering (quotes } \\
\text { used in text), context, } \\
\text { check for resonance } \\
\text { and relevance, } \\
\text { reinterpretation of data } \\
\text { material }\end{array}$ \\
\hline $\begin{array}{l}\text { Face-to-face interviews } \\
\text { and a few follow ups via } \\
\text { telephone: (The total } \\
\text { number of interviews } \\
\text { exceeds the number of } \\
\text { persons as we had } \\
\text { several interviews with } \\
\text { some managers and shop } \\
\text { stewards) }\end{array}$ & $\begin{array}{l}\text { Managers, } \\
\text { financial } \\
\text { advisors, } \\
\text { customer rep., } \\
\text { shop stewards, } \\
\text { union reps., } \\
\text { (30). Board } \\
\text { members union } \\
\& \text { trade org. (4), } \\
\text { Advisor FSA } \\
\text { Norway (1) } \\
\text { Total: 40 }\end{array}$ & $\begin{array}{l}\text { Context data, sales } \\
\text { rhetoric/incentives/ } \\
\text { practices, impacts of } \\
\text { financial crisis, trust, } \\
\text { image, regulation }\end{array}$ & $\begin{array}{l}\text { Verbatim } \\
\text { transcriptions, } \\
\text { sound files }\end{array}$ & \multirow[t]{4}{*}{$\begin{array}{l}\text { Looking for patterns, } \\
\text { anomalies, the } \\
\text { empirical material has } \\
\text { been coded and } \\
\text { categorized, discussed } \\
\text { with involved parties, } \\
\text { recoded and } \\
\text { reinterpreted. } \\
\text { Comparing across } \\
\text { functions, regions and } \\
\text { branches }\end{array}$} \\
\hline $\begin{array}{l}\text { Email interviews } \\
\text { /correspondence on } \\
\text { GFC, sales cultures }\end{array}$ & $\begin{array}{l}\text { Trade union } \\
\text { seminar (30). } \\
\text { Threads from } 1 \\
\text { reply to } 20\end{array}$ & $\begin{array}{l}\text { Sales and customer } \\
\text { orientation post } \\
\text { financial crisis }\end{array}$ & Email texts & \\
\hline Quantitative mapping & $\begin{array}{l}\text { Interviewees, } \\
\text { trade union } \\
\text { seminar }\end{array}$ & $\begin{array}{l}\text { Sales goals vs. } \\
\text { practices: seller } \\
\text { skills, customer } \\
\text { orientation, } \\
\text { performance etc. }\end{array}$ & $\begin{array}{l}\text { Excel charts, } \\
\text { numbers }\end{array}$ & \\
\hline Observation & $\begin{array}{l}15 \text { visits, } 7 \\
\text { different } \\
\text { premises (each } \\
1-2 \text { days) }\end{array}$ & $\begin{array}{l}\text { Organization, } \\
\text { physical layout of } \\
\text { premises, informal } \\
\text { talk }\end{array}$ & $\begin{array}{l}\text { Photographs } \\
\text { Field notes }\end{array}$ & \\
\hline Internal documents & 200 pages & $\begin{array}{l}\text { Institutional self- } \\
\text { presentations, sales, } \\
\text { customer-orientation, } \\
\text { reputation and trust } \\
\text { post crisis }\end{array}$ & $\begin{array}{l}\text { Reports, } \\
\text { presentations, } \\
\text { customer } \\
\text { surveys }\end{array}$ & $\begin{array}{l}\text { Background material } \\
\text { informing data } \\
\text { gathering, checked for } \\
\text { consistency w. } \\
\text { interpretations }\end{array}$ \\
\hline
\end{tabular}

Table A.3: Overview over empirical material and methods post crisis, Nordic financial institutions 2008-2014. 
List of interviewees post crisis in the key cases (for this paper) and at macro level

Case 1: Nordic financial enterprise, personal banking

Length of employment institution Time in current job

Central organization

Vice President Sales

$>5$

$>5$

Shop Steward

$>40$

$>10$

Regional bank A, Norway (NOR)

Chief Executive Officer

Manager, Special Projects

Frontline Sales Manager

$>25$

$>10$

Financial Advisor

Senior Financial Advisor

$>45$

$>5 ?$

Senior Financial Advisor

$>20$

$>15$

Chief Shop Steward

$>30$

$>10$ ?

Shop Steward

$>10$

$>5$

Regional bank B, Denmark (DK)

Assistant Account Manager

Senior Financial Advisor

Senior Financial Advisor

Financial Advisors and

Union Representative (4)

Union Representative

Union Representative

Union Representative

$>+5$

$>$

Customer Representative 
Shop Steward

Case 2: Alliance of saving banks, personal banking

Length of employment institution Time in current job

Regional bank $C$

$\begin{array}{lll}\text { Human Resources Manager } & >5 & >5 \\ \text { Manager at strategic level } & >25 & >20 \\ \text { Manager at strategic level } & >10 & <5 \\ \text { Former Branch Manager } & >30 & >5 \\ \text { Chief Shop Steward } & >25 & >10\end{array}$

Regional bank $D$

Human Resources Manager > $\quad>15$

Chief Shop Steward $>25<5$

* Due to reasons of anonymity the number of years are presented in five-year intervals ( $>5=5-10$ ) and omitted for some informants who are easier to identify or due to lack of data.

\section{Macro level:}

The Finance Sector Union of Norway: 4 members of the Board,

The Norwegian Financial Services Employers' Association: 1 Director The Financial Supervisory Authority in Norway: 1 Advisor/Coordinator

All had more than twenty years of employment within the financial industry in various positions. 